\title{
L'étude des systèmes techniques, une urgence en technologie culturelle
}

Pierre Lemonnier

\section{(2) OpenEdition \\ Journals}

Édition électronique

URL : https://journals.openedition.org/tc/1038

DOI : $10.4000 /$ tc. 1038

ISSN : 1952-420X

Éditeur

Éditions de l'EHESS

Édition imprimée

Date de publication : 1 juin 1983

ISSN : 0248-6016

\section{Référence électronique}

Pierre Lemonnier, «L'étude des systèmes techniques, une urgence en technologie culturelle », Techniques \& Culture [En ligne], 1 | 1983, mis en ligne le 26 janvier 2006, consulté le 29 septembre 2022. URL : http://journals.openedition.org/tc/1038; DOI : https://doi.org/10.4000/tc.1038

Ce document a été généré automatiquement le 29 septembre 2022

Tous droits réservés 


\section{L'étude des systèmes techniques, une urgence en technologie culturelle}

Pierre Lemonnier 